\title{
The Use of Additives to Enhance Properties of Pre- Formed Foamed Concrete
}

\author{
Ameer A. Hilal, Nicholas H. Thom, and Andrew R. Dawson
}

\begin{abstract}
This paper describes an experimental study of an enhancement of pre-formed foamed concrete, $1300-1900 \mathrm{~kg} / \mathrm{m}^{3}$, by utilising two types of additives, silica fume and fly ash, to partially replace Portland cement and fine sand. It focuses on consistency, mechanical and thermal properties as well as presenting a comparison with normal weight, lightweight and foamed concretes from the literature. In addition to conventional foamed concrete mixes (FC), foamed concrete mixes with high flowability and strength (FCa) were also manufactured in this study. The FC mixes had 28-day compressive strengths from 6 to $23 \mathrm{MPa}$ and corresponding thermal conductivities in the dry state from 0.475 to 0.951 $\mathrm{W} / \mathrm{mK}$, whereas for the same density range, the FCa mixes gave 19-47 MPa and $0.498-0.962 \mathrm{~W} / \mathrm{mK}$, respectively. Compared to other studies on foamed concrete, the results from the mixes investigated in this study showed higher strengths (for a given density), higher tensile to compressive strength ratios and higher moduli of elasticity.
\end{abstract}

Index Terms-Foamed concrete, mineral admixture, mechanical properties, thermal conductivity.

\section{INTRODUCTION}

In construction projects, the main use of lightweight concrete is to reduce the dead load of concrete structures resulting in reduction in the size of columns, beams, foundations and other load bearing elements [1]. Cellular (aerated) concrete is a lightweight material composed of cementitious mortar surrounding disconnected bubbles which are a result of either physical or chemical processes during which either air is introduced into the mortar mixture or gas is formed within it [2]. Although aerated concrete is known as an insulation material, its structural features are also of considerable interest [3].

Indeed, the future need for construction materials which are light, durable, economic and environmentally sustainable has been identified by many groups around the world [4].

With the possibility of producing a wide range of densities (400-1600) $\mathrm{kg} / \mathrm{m}^{3}$ and also of achieving a strength of at least $25 \mathrm{MPa}$, foamed concrete has the potential to fulfil these requirements and it is now widely used in the construction industry [4], [5]. Furthermore, with foamed concrete, sustainability can be enhanced because no coarse aggregate is required in its manufacturing and there is also

Manuscript received May 26, 2014; revised July 23, 2014. This work was supported by the Higher Committee for Education Development in Iraq (HCED).

A. A. Hilal was with the University of Al-Anbar, Iraq and now he is with the Department of Civil Engineering, Faculty of Engineering, the University of Nottingham, UK (e-mail: evxaah@nottingham.ac.uk).

N. H. Thom and A. R. Dawson are with the Department of Civil Engineering, Faculty of Engineering, and the University of Nottingham, UK (e-mail: nicholas.thom@nottingham.ac.uk,

Andrew.Dawson@nottingham.ac.uk). the possibility of partially or fully replacing fine aggregate with recycled or secondary materials [6].

The most available supplementary cementing materials are silica fume, a by- product of the reduction of high-purity quartz with coal in electric furnaces in the production of silicon and ferrosilicon alloys, and fly ash, a by-product of the burning of coal in thermal power stations [7]-[10]. Fly ash has the potential to enhance properties by reducing heat of hydration and giving the material good thermal insulation [4], while silica fume is usually added to improve cement paste/aggregate bonds [11]. However, in a study of the effect of mineral admixtures in lightweight concrete with high strength and workability, Reference [8] investigated both rheological (improving the workability) and strength (deceasing the early-age strength) properties, and recommended that fly ash (FA) should not be added to lightweight concrete on its own. In relation to silica fume (SF), he found that it significantly improved early-age strength and increased the bonding of the concrete mixtures, but that it caused rapid reduction in the workability. Bearing these conflicting finding in mind, both FA (as a fine aggregate replacement) and SF (as a cement replacement) were investigated in this study. The ultimate aim was to push back the limits of foamed concrete achieving strengths suitable for semi-structural or structural purposes but with enhanced strength/weight ratio and excellent thermal properties. For this purpose, properties of enhanced foamed concrete will be compared to normal weight, lightweight and foamed concretes produced in other studies.

\section{EXPERIMENTAL DETAILS}

\section{A. Materials}

Combinations of the following constituent materials were used to produce foamed concrete in this study.

- Portland cement CEM I-52,5 N (3.15 S.G.) conforming to BS EN 197-1:2011 [12].

- Natural fine aggregate (sand) (2.65 S.G.) conforming to BS 882:1992 [13] with additional sieving to remove particles greater than $2.36 \mathrm{~mm}$, to help improve the flow characteristics and stability of the final product [4], [14].

- Fresh, clean and drinkable water

- Foam: the quality of foam is critical to the stability of foamed concrete and will affect the strength and stiffness of the final product; therefore, good quality foam $\left(45 \mathrm{~kg} / \mathrm{m}^{3}\right)$ was produced by blending the foaming agent, EABASSOC (1.05 S.G.), water and compressed air in predetermined proportions $(45 \mathrm{~g}$ water to $0.8 \mathrm{ml}$ foaming agent) in a foam generator, STONFOAMM-4. 
- Superplasticizer: MIGHTY 21 EG made by Kao Chemical $\mathrm{GmbH}$ of density $\left(1.1 \mathrm{~g} / \mathrm{cm}^{3}\right)$, was used as a water-reducing agent to maintain sufficient workability of the premixed mortar (without foam) and to produce a high strength foamed concrete with low water/binder ratio. In addition, this superplasticizer has been proved to be compatible with the EABASSOC foaming agent [15].

- Silica fume: Elkem Microsilica (2.2 S.G., 92\% SiO2, mean particle size $0.15 \mu \mathrm{m}$ and specific surface 20 $\mathrm{m}^{2} / \mathrm{g}$ ) made by Elkem A Bluestar Company was used to fill the space between cement particles making the cement matrix denser and stronger, to gain early age strength and to improve cement/aggregate bonds.

- Fly Ash: to gain high strength and achieve more uniform distribution of air voids, CEMEX fly ashclass S (2.09 S.G.) conforming to BS EN 405-1:2005 [16], was used instead of part of the fine sand in the production of foamed concrete.

\section{B. Mix Proportions}

In this study, mix proportioning began with the selection of the unit weight (wet density), the cement content and the water to cement ratio. The mix was then proportioned by the method of absolute volumes.

It has been reported that mix proportions of concrete should be chosen according to particular requirements such as strength, shrinkage, thermal conductivity etc. For this reason and based on the best findings from the literature, the constituent materials selected for this project have been chosen to produce foamed concrete with relatively high strength and good thermal properties.

Reference [15] stated that based on previous studies, (Indian concrete Journal, 1989; ACI, 1993; Valore, 1954), cement content in conventional foamed concrete with or without sand should be between 250 and $500 \mathrm{~kg} / \mathrm{m}^{3}$; in this project, to produce foamed concrete with high strength it was chosen to be $500 \mathrm{~kg} / \mathrm{m}^{3}$.

The stability, the state of the mix at a density ratio (measured fresh density divided by design density) close to unity, and consistency, spreadability and flowability measurements, of foamed concrete are affected by the volume of foam and water-solid ratio [17], [18]. Therefore, in this study for each mix the water/binder ratio required to produce a stable mix (density ratio close to unity) was determined by trials while the required foam volume was determined from the mix design.

It is accepted that to achieve the target flow value, the proper dosage of superplasticizer should be determined by trial and error. Noting that in this study there is no target flow value but there is a target density which is affected by water content and foam volume, therefore a single dosage of superplasticizer $(1.5 \%)$ was obtained from trials and adopted for all relevant mixes.

It has been well documented that the use of silica fume as a partial replacement of cement in combination with superplasticizer provides a significant increase in the strength and decrease in the permeability of concrete [19], and proportions up to $10 \%$ by mass of cement have been reported [18]. Moreover and according to Reference [20], when silica fume is used (usually no more than $10 \%$ of cement weight), there is no reduction in the fracture energy. In addition, based on the Taguchi method, Reference [21] concluded that at $20^{\circ} \mathrm{C}$ the optimum for both compressive and flexural strength is $10 \%$ silica fume by mass; therefore, where used in this project, silica fume has been added to the mix at $10 \%$ of the cement weight.

TABLE I: Mix Proportions OF 1300 KG/M³ FOAMED CONCRETE MiXeS

\begin{tabular}{|c|c|c|c|c|c|c|}
\hline & \multicolumn{6}{|c|}{ Mixes } \\
\hline & FC3 & FC3s & FC3f & FC3p & $F C 3 p+s$ & FCa3 \\
\hline $\begin{array}{l}\text { Target density } \\
\left(\mathrm{kg} / \mathrm{m}^{3}\right)\end{array}$ & 1300 & 1300 & 1300 & 1300 & 1300 & 1300 \\
\hline $\begin{array}{l}\text { Cement content } \\
\left(\mathrm{kg} / \mathrm{m}^{3}\right)\end{array}$ & 500 & 450 & 500 & 500 & 450 & 450 \\
\hline $\begin{array}{ll}\begin{array}{l}\text { Silica } \\
\left(\mathrm{kg} / \mathrm{m}^{3}\right)\end{array} & \text { Fume } \\
\end{array}$ & - & 50 & - & - & 50 & 50 \\
\hline w/b ratio* & 0.475 & 0.475 & 0.475 & 0.3 & 0.3 & 0.3 \\
\hline $\begin{array}{l}\text { Superplasticizer } \\
\left(\mathrm{kg} / \mathrm{m}^{3}\right)\end{array}$ & - & - & - & 7.5 & 7.5 & 7.5 \\
\hline $\begin{array}{l}\text { Water content } \\
\left(\mathrm{kg} / \mathrm{m}^{3}\right)\end{array}$ & 237.5 & 237.5 & 237.5 & 150 & 150 & 150 \\
\hline $\begin{array}{l}\text { Sand content } \\
\left(\mathrm{kg} / \mathrm{m}^{3}\right)\end{array}$ & 562 & 562 & 450 & 625 & 625 & 500 \\
\hline Fly Ash $\left(\mathrm{kg} / \mathrm{m}^{3}\right)$ & - & - & 112 & - & - & 125 \\
\hline Foam $(\mathrm{kg} / \mathrm{m3})$ & 19.1 & 19.1 & 19.1 & 19.1 & 19.1 & 19.1 \\
\hline Foam $\left(m^{3}\right)$ & 0.424 & 0.424 & 0.424 & 0.424 & 0.424 & 0.424 \\
\hline
\end{tabular}

TABLE II: Mix Proportions OF SELECTED FoAMEd CONCRETE MiXeS

\begin{tabular}{|c|c|c|c|c|c|c|}
\hline & \multicolumn{6}{|c|}{ Mixes } \\
\hline & FC3 & FCa3 & FC6 & FCa6 & FC9 & FCa9 \\
\hline $\begin{array}{l}\text { Target density } \\
\left(\mathrm{kg} / \mathrm{m}^{3}\right)\end{array}$ & 1300 & 1300 & 1600 & 1600 & 1900 & 1900 \\
\hline $\begin{array}{l}\text { Cement content } \\
\left(\mathrm{kg} / \mathrm{m}^{3}\right)\end{array}$ & 500 & 450 & 500 & 450 & 500 & 450 \\
\hline $\begin{array}{ll}\begin{array}{l}\text { Silica } \\
\left(\mathrm{kg} / \mathrm{m}^{3}\right)\end{array} & \text { Fume } \\
\end{array}$ & - & 50 & - & 50 & - & 50 \\
\hline w/b ratio* & 0.475 & 0.3 & 0.5 & 0.325 & 0.525 & 0.35 \\
\hline $\begin{array}{l}\text { Superplasticizer } \\
\left(\mathrm{kg} / \mathrm{m}^{3}\right)\end{array}$ & - & 7.5 & - & 7.5 & - & 7.5 \\
\hline $\begin{array}{l}\text { Water content } \\
\left(\mathrm{kg} / \mathrm{m}^{3}\right)\end{array}$ & 237.5 & 150 & 249.9 & 162.5 & 262.5 & 175 \\
\hline $\begin{array}{l}\text { Sand content } \\
\left(\mathrm{kg} / \mathrm{m}^{3}\right)\end{array}$ & 562 & 514 & 850 & 744 & 1137.5 & 974 \\
\hline Fly Ash $\left(\mathbf{k g} / \mathbf{m}^{3}\right)$ & - & 128.5 & - & 186 & - & 243.5 \\
\hline Foam $(\mathrm{kg} / \mathrm{m3})$ & 19.1 & 19.1 & 13.3 & 13.3 & 7.5 & 7.5 \\
\hline $\begin{array}{l}\text { Foaming agent } \\
(\mathrm{kg} / \mathrm{m} 3)\end{array}$ & 0.35 & 0.35 & 0.24 & 0.24 & 0.14 & 0.14 \\
\hline Foam $\left(\mathbf{m}^{3}\right)$ & 0.424 & 0.424 & 0.295 & 0.295 & 0.166 & 0.166 \\
\hline
\end{tabular}

${ }^{*} \mathrm{w} / \mathrm{b}$ ratios required to achieve a density ratio of unity for the selected mixes

Reference [22] stated that, in foamed concrete, because fly ash is a reactive material, replacement of sand with fly ash leads to increased strength. On the other hand, this will also lead to increased water absorption. In addition, according to [18], mixes with fly ash exhibit higher carbonation than those with sand. Furthermore, using sand may lead to improved shear capacity between its particles and the paste resulting in higher tensile strength. For these reasons and to make the lightest mix $\left(1300 \mathrm{~kg} / \mathrm{m}^{3}\right)$ suitable for structural purposes, in addition to adding silica fume and superplasticizer, fly ash replacement was limited to $20 \%$ by weight of fine sand (Table I), giving a strength of over 17 MPa (see Section 3.1) and thereby bringing it into the range where it may be considered a structural concrete [23]. To 
enable sensible comparisons, this ratio was also adopted for the 1600 and $1900 \mathrm{~kg} / \mathrm{m}^{3}$ mixes with additives (FCa6 and FCa9), see Table II.

\section{Production}

To produce foamed concrete, the equipment used in this study comprised: an ordinary mixer for mixing the raw materials, a foam generator (STONEFOAM-4) running on a $12 \mathrm{Vdc}(40-50 \mathrm{~A})$ battery for generating stable foam by blending a foaming agent, EABASSOC (1.05 S.G.), water and compressed air of predetermined proportions (45 $\mathrm{g}$ water to $0.8 \mathrm{ml}$ foaming agent) in it, and moulds for casting the specimens. In this study, six differently proportioned mixes were designed and divided into two groups, conventional mixes (FC) and mixes with additives (FCa), each one at three densities, 1300 (FC3 and FCa3), 1600 (FC6 and FCa6) and 1900 (FC9 and FCa9) $\mathrm{kg} / \mathrm{m}^{3}$. In moulding the specimens $[12$ cubes $(100 \times 100 \times 100 \mathrm{~mm}), 6$ prisms $(100 \times 100 \times 500 \mathrm{~mm}), 2$ cylinders $(150 \times 300 \mathrm{~mm})$ and 1 slab $(305 \times 305 \times 50 \mathrm{~mm})$ for each $\mathrm{mix}]$, the foamed concrete mix was placed in two approximately equal layers. The sides of the moulds were lightly tapped after placing each layer until the surface of the layer had subsided approximately to level [24]. After filling the moulds, the surfaces of the specimens were levelled by using a trowel. All specimens were covered with thick nylon to prevent evaporation. All specimens were removed from moulds after 24 hours. After de-moulding, the specimens were sealed-cured (wrapped in cling film) and stored at $20^{\circ} \mathrm{C}$ until testing. Note that sealed-curing reflects a typical industry practice for foamed concrete [4].

\section{RESUlTS AND DisCUSSION}

\section{A. Effect of Additives}

As explained above, to develop the selected foamed concrete mixes, comprising superplasticizer, silica fume and fly ash at specified ratios were added to a proportion of the mixes. To identify the effect of additives, individually or together, on the strength, a preliminary experimental programme was carried out at the lowest material density $\left(1300 \mathrm{~kg} / \mathrm{m}^{3}\right)$, see Table I. The results are shown in Fig. 1, where it may be seen that adding silica fume (FC3s) or fly ash (FC3f) individually improved the 28-day compressive strength by about $10 \%$ and $60 \%$ respectively. In addition, the use of superplasticizer (FC3p) improved the compressive strength by $115 \%$ (at 28-day); this increased to $125 \%$ with combined of silica fume and superplasticizer $(\mathrm{FC} 3 \mathrm{~s}+\mathrm{p})$. However, the further addition of fly ash (FCa3), helped in achieving a great increase in strength $(215 \%)$ making even this lightest mix potentially suitable for structural purposes.

\section{B. Consistency}

The consistency of both the base mix and foamed concrete was quantified by measuring the spread diameter of a cylinder of material of initial diameter $75 \mathrm{~mm}$ and 150 mm height (Fig. 2) [17], [25]. The spreadability variation with mix density before and after addition of foam is illustrated in Fig. 3. It seems that for the three densities adopted, the spreadability of base and foamed concrete mixes was 200-250 $\mathrm{mm}$ and 140-180 $\mathrm{mm}$, respectively, for the conventional mixes (FC) while it was $400-450 \mathrm{~mm}$ and 290-350 mm, respectively, for the mixes with additives (FCa). It is evident that for a given mix, the spreadability reduces when the foam is added and for the selected mixes it also reduces with a reduction in design density; similar behaviour has been reported in the literature [17], [26]. Reference [26] suggested that the reason for this may be that the adhesion between the bubbles and solid particles in the mixture increases the stability of the paste resulting in reduced spreadability, noting that there are more bubbles at the lower densities, see Fig. 4.

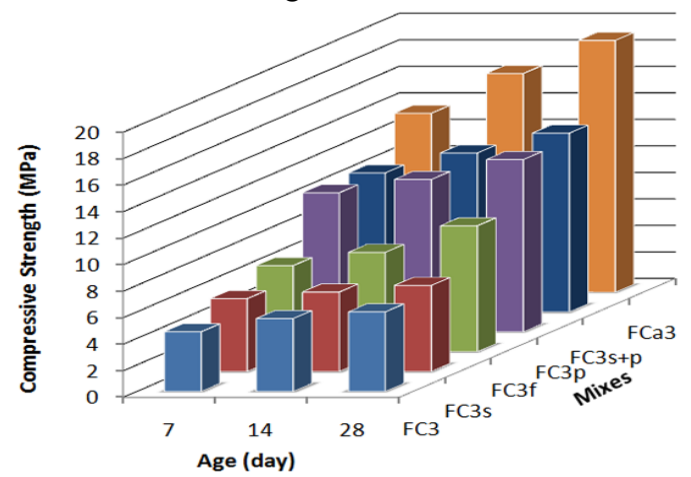

Fig. 1. Effect of used additives on the compressive strength of $1300 \mathrm{~kg} / \mathrm{m} 3$ mix.
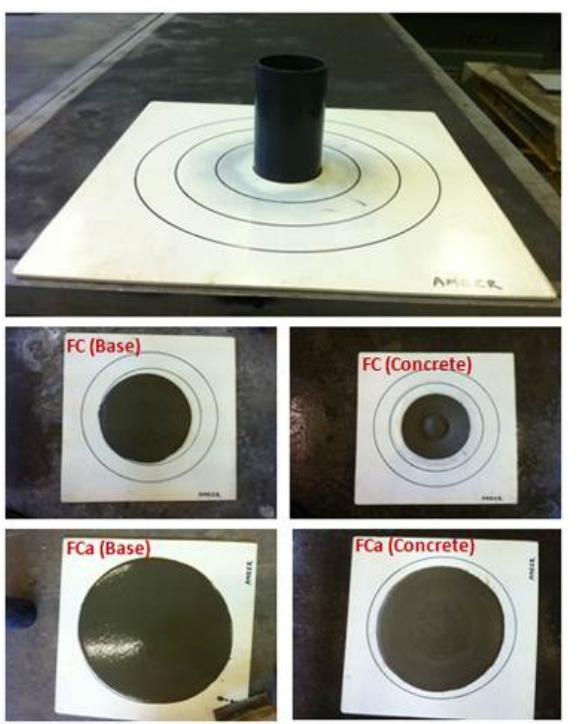

Fig. 2. Test of the spreadability of the base mix and foamed concrete.

\section{Mechanical Properties}

\section{1) Compressive strength}

Compressive strength testing was carried out on $100 \mathrm{~mm}$ cubes in accordance with BS EN 12390-3:2002 [27] and in each case the results quoted are the average of three specimens. As expected [4], [26], the compressive strength of foamed concrete decreases dramatically with a reduction in density, as shown in Fig. 5. As illustrated in Fig. 6, the use of additives (silica fume (SF), fly ash (FA) and superplasticizer) greatly improved compressive strength development at all test ages. This is because of the reduction in water content due to use of a superplasticizer and the pozzolanic characteristics of both SF and FA, leading to an improved aggregate-matrix bond associated with the formation of a less porous interfacial zone and a 
better interlock between the paste and the aggregate [19], (see Fig. 7a, b). In addition, using FA as filler may help in achieving more uniform distribution of air-voids by providing uniform coating on each bubble thereby preventing merging of bubbles leading to an increase in strength [18], [28] (Fig. 7c, d).

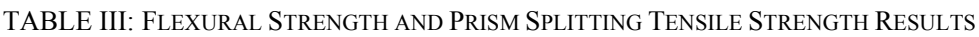

\begin{tabular}{|c|c|c|c|c|c|c|c|c|c|}
\hline \multirow{3}{*}{ Mixes } & \multicolumn{9}{|c|}{ Test Age (day) } \\
\hline & \multicolumn{3}{|c|}{7} & \multicolumn{3}{|c|}{14} & \multicolumn{3}{|c|}{28} \\
\hline & $\begin{array}{l}\text { Density } \\
\left(\mathrm{kg} / \mathrm{m}^{3}\right)\end{array}$ & $f_{\mathrm{r}}(\mathrm{MPa})$ & $\begin{array}{c}f_{\text {sp }} \\
(\mathbf{M P a})\end{array}$ & $\begin{array}{l}\text { Density } \\
\left(\mathrm{kg} / \mathrm{m}^{3}\right)\end{array}$ & $f_{\mathrm{r}}(\mathrm{MPa})$ & $\begin{array}{c}f_{\text {sp }} \\
(\mathbf{M P a})\end{array}$ & $\begin{array}{l}\text { Density } \\
\left(\mathrm{kg} / \mathrm{m}^{3}\right)\end{array}$ & $f_{\mathrm{r}}(\mathrm{MPa})$ & $\begin{array}{c}f_{\mathrm{sp}} \\
(\mathrm{MPa})\end{array}$ \\
\hline FC3 & 1280 & 1.2 & 0.65 & 1295 & 1.3 & 0.75 & 1285 & 1.4 & 0.85 \\
\hline FCa3 & 1320 & 2.1 & 0.85 & 1323 & 2.6 & 1.35 & 1316 & 2.8 & 1.65 \\
\hline FC6 & 1615 & 2.3 & 0.9 & 1620 & 2.7 & 1.5 & 1625 & 2.9 & 1.8 \\
\hline FCa6 & 1605 & 3.4 & 1.7 & 1620 & 3.8 & 2.35 & 1630 & 4.1 & 2.65 \\
\hline FC9 & 1870 & 2.9 & 1.5 & 1880 & 3.2 & 2.15 & 1865 & 3.7 & 2.35 \\
\hline FCa9 & 1870 & 4.1 & 2.5 & 1875 & 4.5 & 3.1 & 1880 & 5.3 & 3.5 \\
\hline
\end{tabular}

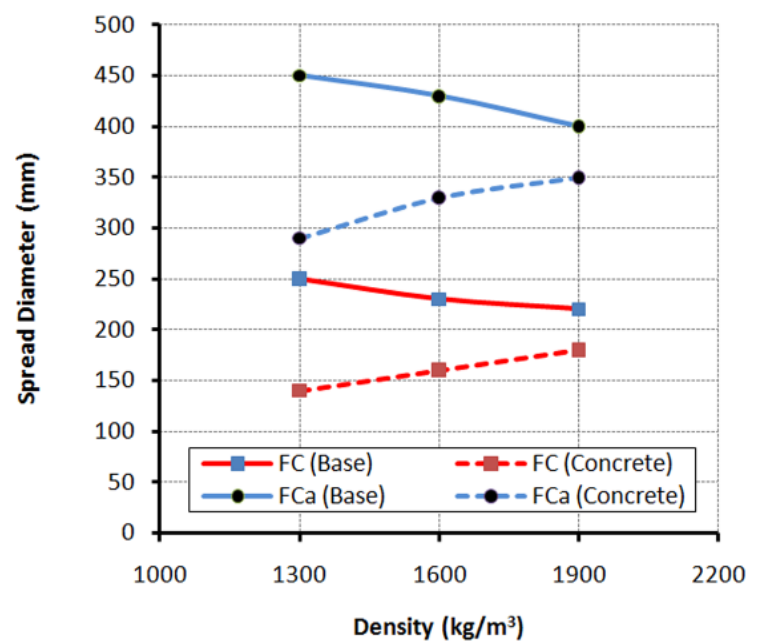

Fig. 3. Variation of spreadability with density of the base and foamed concrete mixes.
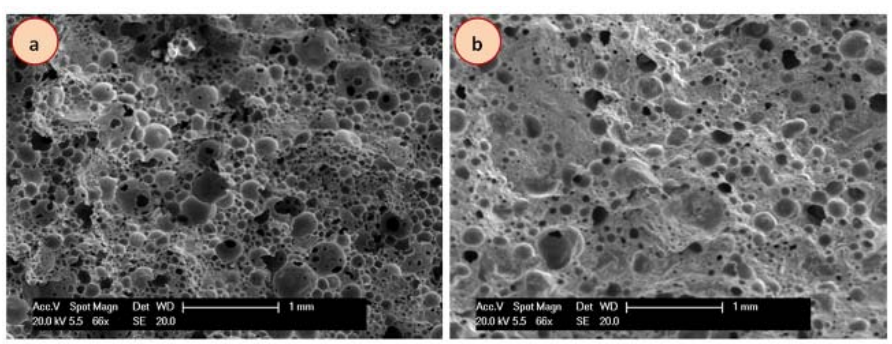

Fig. 4. Air voids in foamed concrete: (a) $1300 \mathrm{~kg} / \mathrm{m}^{3}$ density (b) 1900 $\mathrm{kg} / \mathrm{m}^{3}$ density.

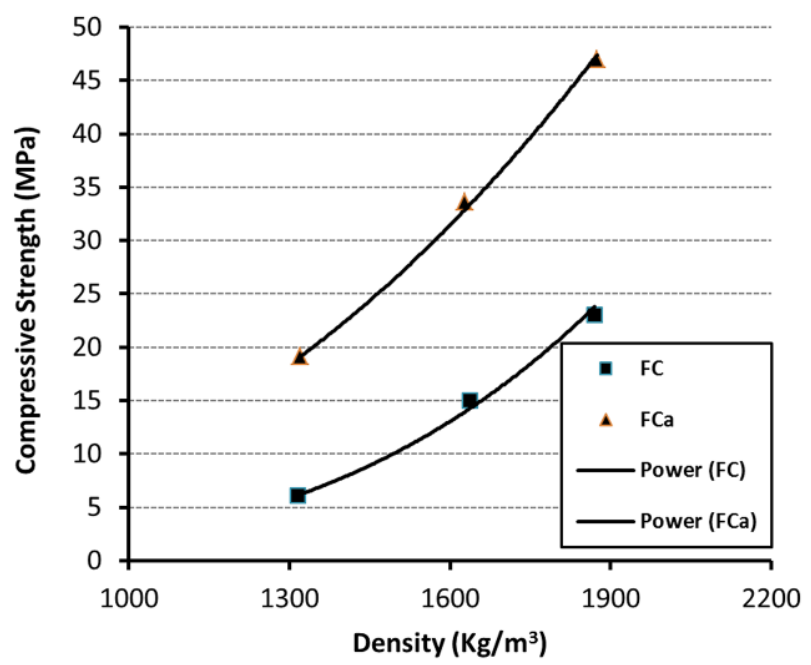

Fig. 5. 28 day compressive strength density variation for FC and FCa mixes.
In general, it is reported that foamed concrete with fly ash as filler has a higher strength to density ratio for all densities [26]. A comparison of strength to density ratios between FC and FCa mixes, at 28 days, with foamed concrete mixes from the literature [4], [26], [29] is shown in Fig. 8. Based on this comparison, it would appear that the FCa mixes showed higher strength to density ratios than any of the foamed concrete mixes in other studies produced by using sand and/or fly ash as a filler material. Overall, except for mixes FC3 and FC6, the results suggest that the remaining mixes are all potentially suitable for use as a lightweight concrete for semi-structural or structural purposes since their densities to not exceed $2000 \mathrm{~kg} / \mathrm{m}^{3}$ and their 28-day compressive strengths are in excess of $17 \mathrm{MPa}$ [1], [23].

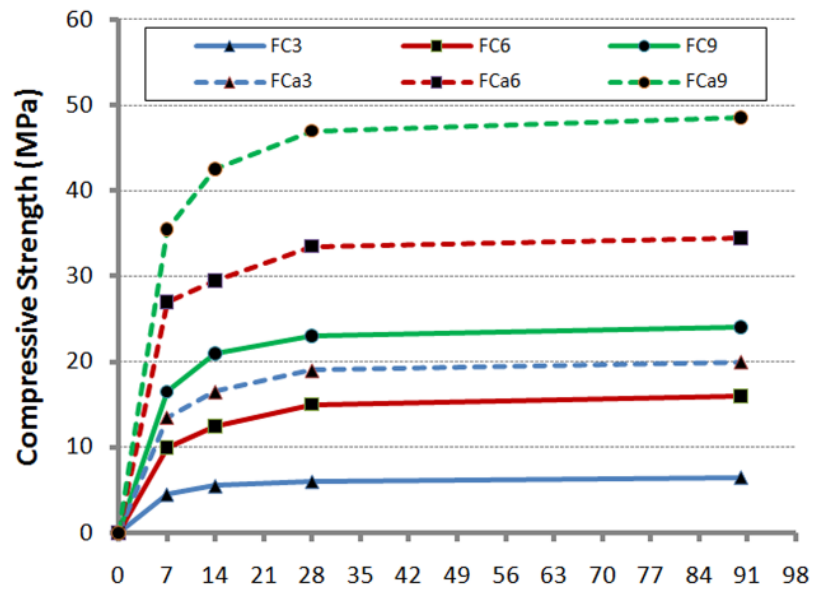

Age (Day)

Fig. 6. Development of $100 \mathrm{~mm}$ cube sealed-cured compressive strength.

The structural properties of concrete such as shear resistance, bond strength and resistance to cracking depend on the tensile strength; the higher the tensile strength the better the structural properties [30]. Flexural strength testing (two-point loading) was conducted on two $100 \times 100 \times 500$ $\mathrm{mm}$ prisms at ages of 7,14 and 28 days to determine the modulus of rupture $\left(f_{\mathrm{r}}\right)$ in accordance with BS EN 12390-5: 2000 [31]. Splitting tensile strength $\left(f_{\mathrm{sp}}\right)$ testing was also undertaken, in accordance with BS1881-117: 1983 [32] and in each case the mean of three tested values at each test age was recorded. The averaged values of $f_{\mathrm{r}}$ and $f_{\mathrm{sp}}$ are summarized in Table III. Those at 28 days are compared with corresponding 28-day compressive strengths in Figures 9 and 10, respectively. Note that in Fig. 9 the FC, LWC and 
NWC graphs were plotted from equations $f_{\mathrm{r}}=0.31\left(f^{\prime}\right)^{0.83}$, $f_{\mathrm{r}}=0.46\left(f^{\prime}{ }_{\mathrm{c}}\right)^{2 / 3}$ and $f_{\mathrm{r}}=0.438\left(f^{\prime}{ }_{\mathrm{c}}\right)^{2 / 3}$ respectively [30], [33], [34], and that in Fig. 10 the LWC and NWC graphs were plotted from equations $f_{\mathrm{sp}}=0.28\left(f^{\prime}{ }_{\mathrm{c}}\right)^{0.69}$ and $f_{\mathrm{sp}}=0.2\left(f_{\mathrm{c}}\right)^{0.7}$ respectively [30], [35]. It can be seen from the two figures that, for a given 28-day compressive strength, the conventional mixes (FC) produced higher indirect tensile strengths, flexural and splitting, than those with additives (FCa). The reason for this may be the improved shear capacity between the sand particles and the paste phase [4] noting that, for a given density, the sand content is lower in the mixes with additives (FCa). However, $f_{\mathrm{sp}} / f_{\mathrm{cu}}$ ratios for both FC and FCa mixes were slightly higher than those reported in most other studies [4], [30], [35], while, the tensile $\left(f_{\mathrm{r}}\right.$ or $\left.f_{\mathrm{sp}}\right) /$ compressive strength $\left(f_{\mathrm{cu}}\right)$ ratios of both FC and FCa mixes were slightly lower than those investigated by [30], likely to be because of the presence of lightweight aggregate in these mixes which may lead to improved its tensile strength. As illustrated in Fig. 11, at an age of 28 days, $f_{\mathrm{r}}$ values of about $16-23 \%$ and $11-15 \%$ of $f_{\text {cu }}$ were observed for FC and FCa mixes respectively, while the ranges for $f_{\mathrm{sp}}$ were about $10-14 \%$ and 7-9 \% of $f_{\mathrm{cu}}$.
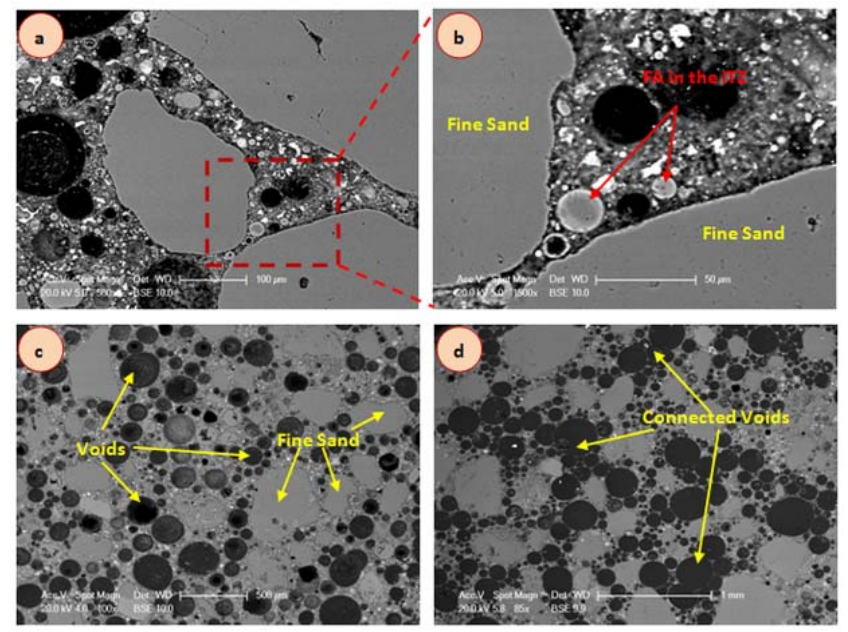

Fig. 7. Scanning Electron Microscopy images of $1300 \mathrm{~kg} / \mathrm{m} 3$ foamed concrete ( $\mathrm{a}, \mathrm{b}$ and $\mathrm{c}$ ) with additives (FCa3), (d) conventional.

W

Fig. 8. Strength to density ratios for different foamed concrete mixes.

\section{1) Tensile (flexural and splitting) strength}

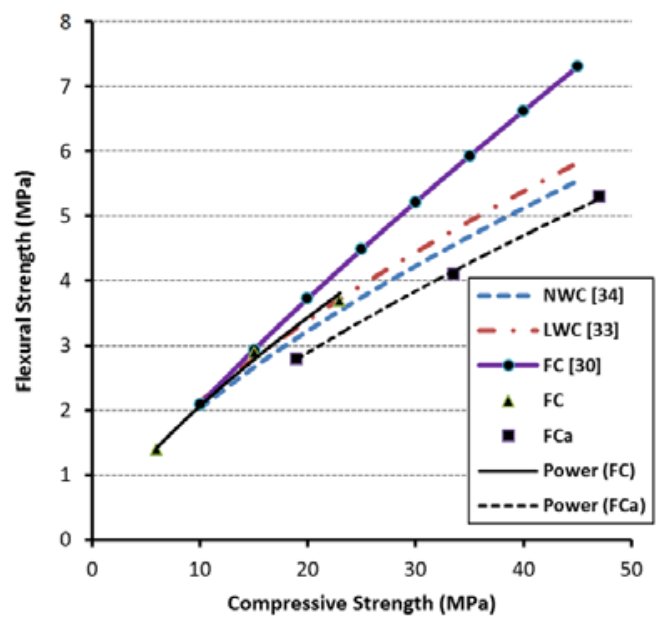

Fig. 9. Relationship between flexural strength and 28 day compressive strength of foamed, LW and NW concretes.

\section{2) Modulus of elasticity}

The static modulus of elasticity $\left(E_{s}\right)$ of the mixtures was determined using $150 \times 300 \mathrm{~mm}$ cylinder specimens. Two specimens were tested for each mix at an age of 28 days in accordance with BS 1881-121: 1983 [36]. Each specimen was fitted with four potentiometers at different quadrants to measure the axial deformation. $E_{s}$ was determined from the slope of the stress-strain compression curves. The relationship with corresponding 28-day sealed-cured cube compressive strengths is given in Fig. 12.

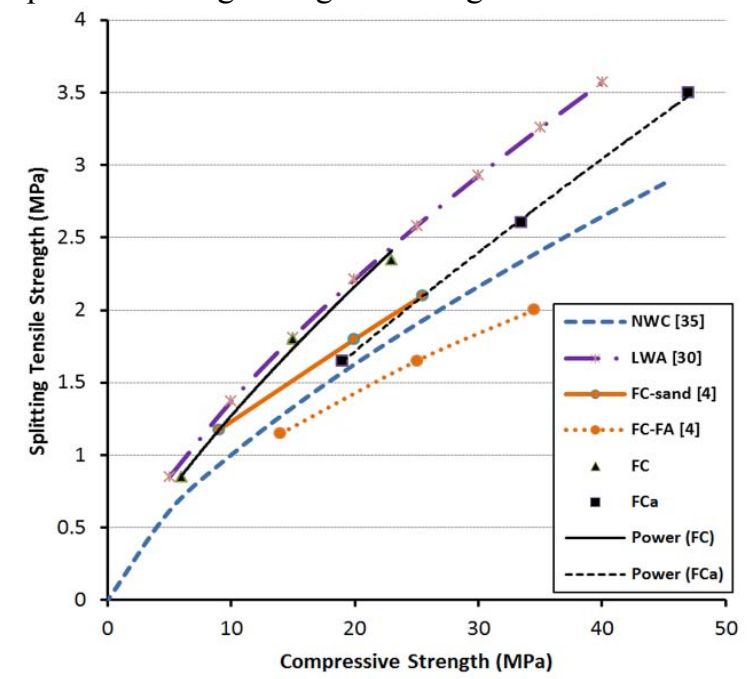

Fig. 10. Relationship between splitting tensile strength and 28 day compressive strength of foamed, LW and NW concretes.

Note that the FC-FA, FC-Sand, LWC and NWC graphs were plotted from equations $E_{c}=0.99\left(f_{\mathrm{cu}}\right)^{0.67}$, $E_{c}=0.42\left(f_{\mathrm{cu}}\right)^{1.18}, \quad E_{c}=1.7 \times 10^{-6}\left(f^{\prime}{ }_{\mathrm{c}}\right)^{2}\left(f_{\mathrm{cu}}\right)^{0.33} \quad$ and $E_{c}=11.71\left(f^{\prime}{ }^{\prime}\right)^{0.33}-8.355$ respectively [4], [37], [38]. It can be seen that for a given compressive strength, the FCa mixes exhibited lower $E$-values than the FC mixes, while the $E_{s}$ for NWC was higher than for both FC and FCa. The same behaviour was observed by Jones and McCarthy [4] leading then to conclude that a direct substitution of foamed concrete for the same compressive strength grade of normal concrete will not in reality give similar structural performance.

The dynamic modulus of elasticity $\left(E_{d}\right)$ was measured according to BS 1881-203: 1986 [39] using a CNS Farnell PUNDIT, Portable Ultrasonic Non-destructive Digital Indicating Tester. The relationships between the static $\left(E_{s}\right)$ and dynamic $\left(E_{d}\right)$ moduli of elasticity for both FC and FCa mixes are shown in Fig. 13. In this study (as in many others), the $E_{d}$ appears higher than the $E_{s}$ (secant) in all selected mixes. The reason for this is usually ascribed to the use of a $100 \%$ non-destructive approach for determining $E_{d}$ which provides very small applied stress and hence there is neither micro crack formation nor creep during the test [40].

\section{Thermal Conductivity}

Two classes of method are normally used to measure the thermal conductivity of building materials; steady-state methods, in which the temperature across a sample does not change with time, and transient methods, in which a measurement is performed during the process of heating up [41]. 


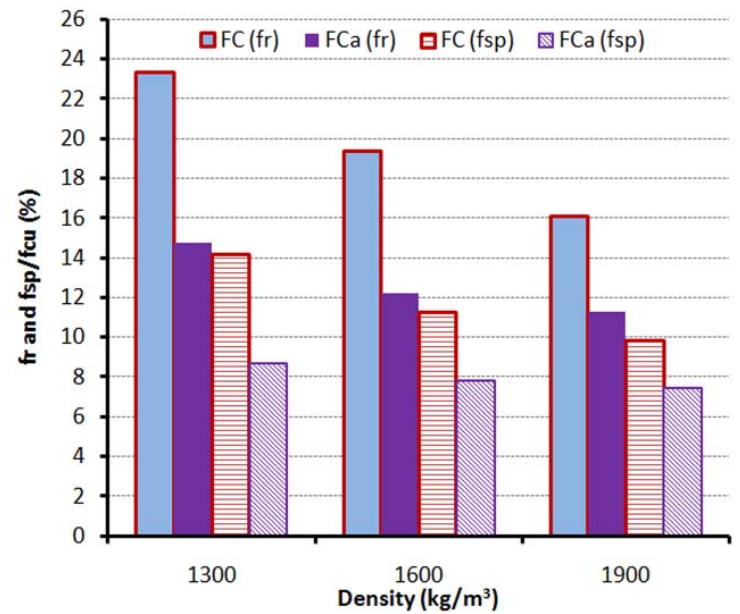

Fig. 11. The ratios of tensile strength ( $f \mathrm{r}$ and $f \mathrm{sp}$ ) to compressive strength of the selected mixes at 28 day.

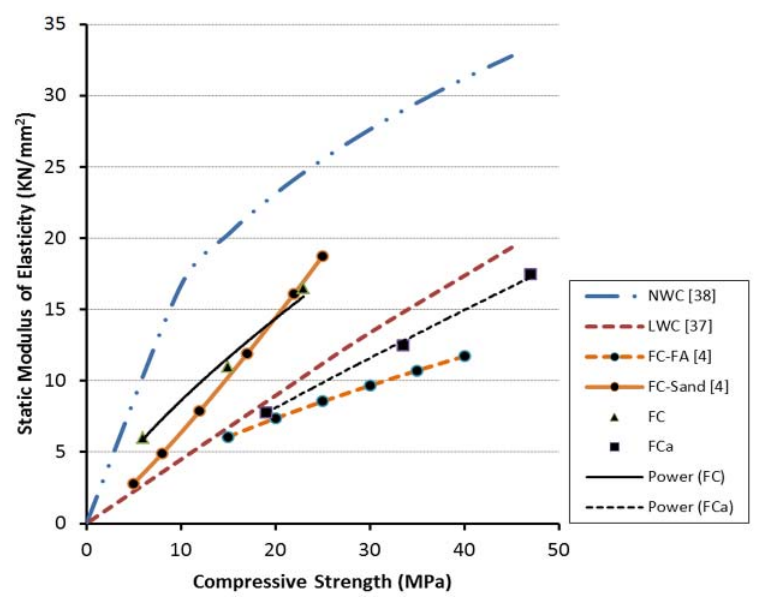

Fig. 12. Relationship between E-values and 28 day compressive strength of foamed, LWC and NWC concretes.

In this study the Heat Flow Meter (HFM) method, introduced in ISO 8301:1996 [42], was adopted to determine the thermal conductivity of all selected mixes. In the HFM technique, the specimen $(305 \times 305 \times 50 \mathrm{~mm})$ is placed between a hot plate and the HFM which is attached to a cold plate. A Thermal Conductivity of Building and Insulating Materials Unit (B480) was used for this test. The results of thermal conductivity for both dry $\left(\lambda_{d}\right.$ - oven-dried at $105^{\circ} \mathrm{C}$ until constant weight) and saturated $\left(\lambda_{\mathrm{s}}\right.$ - immersed in water for 7 days) states are shown in Table IV.

As expected, for a given mix, it was found that the higher the density the higher the thermal conductivity, and that thermal conductivity increases with increased moisture $\left(\lambda_{\mathrm{s}}>\lambda_{\mathrm{d}}\right)$, since air has lower thermal conductivity than water. However, despite the fact that adding fly ash instead of sand leads to an increase in the foam content compared with conventional mixes (FC), the thermal conductivity in the dry state of mixes with additives (FCa) is slightly higher than that for conventional mixes, (Fig. 14). The reason for this is that in the case of foamed concrete, its thermal conductivity depends not only on the air volumetric fraction but also on the thermal conductivity of the solid materials (mortar or cement paste) which is made denser by the physical and chemical contribution of the additives (SF and FA) as well as having less porosity owing to reduced W/C ratio with the addition of a superplasticizer, Fig. 15. In addition, the pore structure of a material plays a dominant role in controlling its thermal conductivity, and it is noted that adding fly ash may lead to a more uniform voids distribution resulting in reduced connectivity and consequent increase in thermal conductivity.

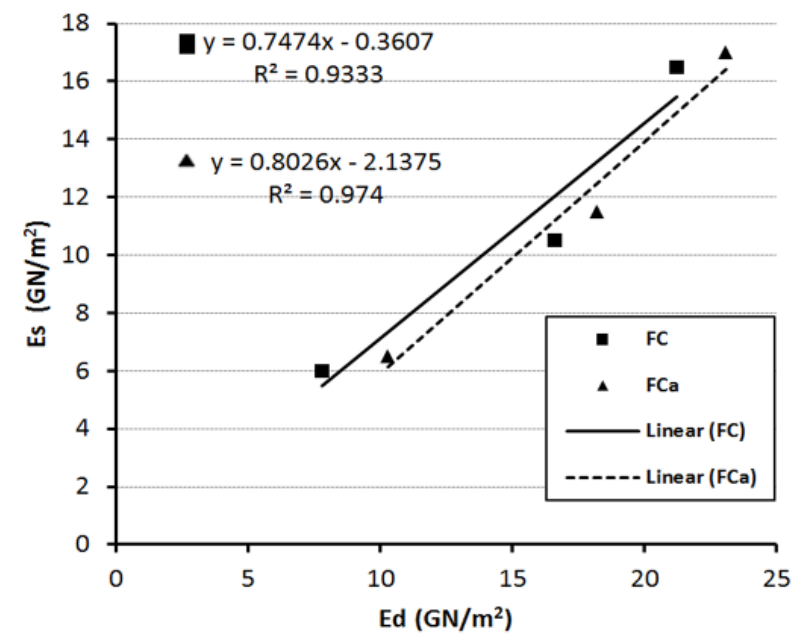

Fig. 13. Relationship between static and dynamic modulus of elasticity at 28 day of foamed concrete mixes.

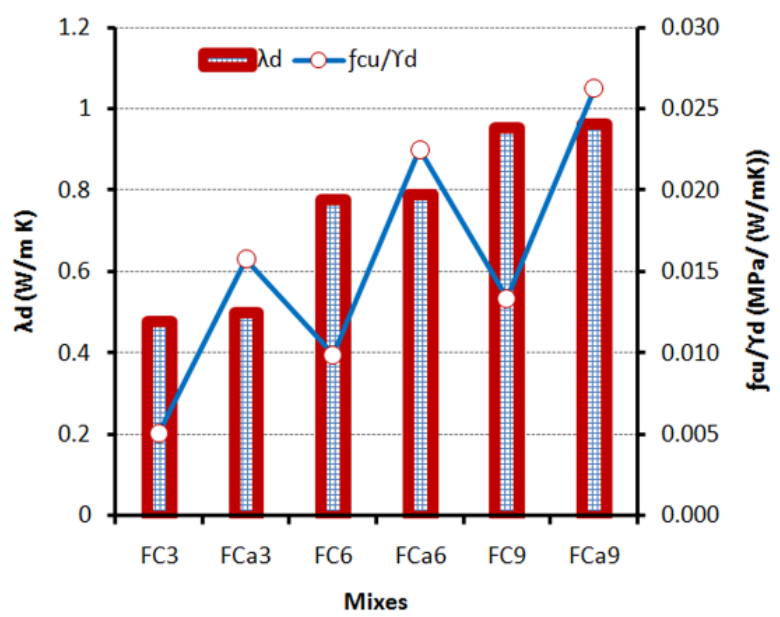

Fig. 14. The variation of $(\lambda d)$ and $(f c u / \lambda d)$ for the selected mixes.

In contrast, in the saturated state and for a given density, the results illustrate that compared to conventional mixes (FC), the thermal conductivities were slightly lower for FCa mixes. This is because the water absorption of $\mathrm{FCa}$ mixes is less than that for FC mixes leading to the water content being lower, which results in reduced thermal conductivity. In other words, the water absorption in foamed concrete is mainly influenced by the paste phase which is denser in the case of $\mathrm{FCa}$ mixes, and not all artificial pores take part in water absorption since they are not interconnected [18], (Fig. 7c). In concrete construction, it is not only beneficial to reduce the thermal conductivity of a material, but also to increase its structural efficiency $\left(f_{\mathrm{c}} / \lambda\right)$. Fig. 14 illustrates that, for all mixes, there is an increase in the $\left(f_{\mathrm{cu}} / \lambda_{\mathrm{d}}\right)$ ratio with increase of density while, for the same density, this ratio increases with the presence of additives. These increases are gained as a result of improvements in the cementitious matrix due to reducing the foam, for the selected mixes, and/or reducing the $\mathrm{W} / \mathrm{C}$ ratio by adding a water reducer and the incorporation of high quality pozzolana (SF and FA), for a given density. A comparison 
of thermal conductivity and $\left(f_{\mathrm{cu}} / \lambda\right)$ for the selected mixes with other mixes (NWC, LWC and FC) from the literature [29], [41] is shown schematically in Fig. 16.
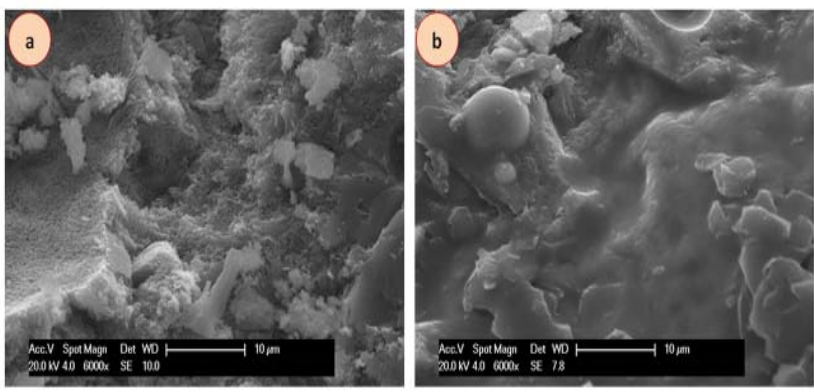

Fig. 15. Microstructure of two $1600 \mathrm{~kg} / \mathrm{m} 3$ foamed concretes (a) Conventional, FC6 (b) with additives, FCa6.

TABLE IV: THE RESUlTS OF THERMAL CONDUCTIVITY FOR BOTH OF DRY AND SATURATED STATES

\begin{tabular}{|c|c|c|c|c|c|c|c|}
\hline \multicolumn{2}{|c|}{ Mixes } & FC3 & FCa3 & FC6 & FCa6 & FC9 & FCa9 \\
\hline $\boldsymbol{\lambda}$ & Dry & 0.475 & 0.498 & 0.775 & 0.789 & 0.951 & 0.962 \\
\cline { 2 - 8 }$(\mathbf{W} / \mathbf{m K})$ & Saturated & 0.635 & 0.599 & 1.08 & 0.986 & 1.185 & 1.112 \\
\hline
\end{tabular}

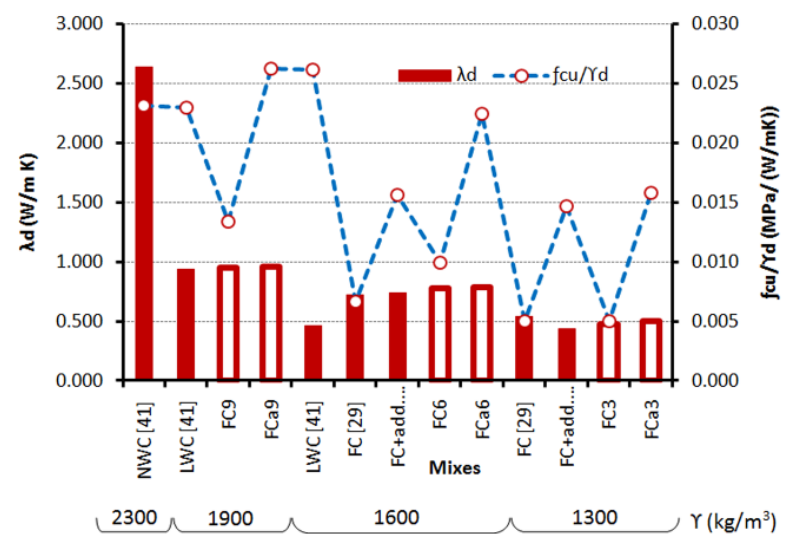

Fig. 16. The comparison of $(\lambda d)$ and $(f \mathrm{cu} / \lambda d)$ for the selected mixes with other mixes (NWC, LWC and FC) [29], [41].

\section{CONCLUSIONS}

From the tests presented in this paper, the following conclusions can be drawn:

- The mineral admixtures (SF and FA) and superplasticizer combination provides improvement in both the workability and the strength properties of foamed concrete.

- The results for mixes investigated in this study showed higher compressive strength to density ratios compared to foamed concrete mixes from other studies produced by using sand and/or fly ash as a filler material.

- While indirect tensile, flexural and splitting strengths were significantly higher for FCa mixes than FC mixes, the tensile/compressive ratios were higher for $\mathrm{FC}$ mixes.

- Similarly, while FCa mixes gave higher Es than FC mixes for a given density, they exhibited lower $E$-values for a given compressive strength. Es for NWC was also higher than both at a given compressive strength.

- Due to their making the cement paste denser and less porous, addition of additives and superplasticizer leads to slightly increased thermal conductivity in the dry state. However, owing to reduced water absorption, the thermal conductivity in the saturated state was slightly lower for FCa mixes than FC mixes.

\section{ACKNOWLEDGEMENT}

The authors would like to acknowledge the support of the Higher Committee for Education Development in Iraq (HCED) for the research scholarship enabling this work to be conducted as part of a larger research project.

\section{REFERENCES}

[1] S. H. Kosmatka, W. C. Panarese, and P. C. Association, "Design and control of concrete mixtures," Portland Cement Association Skoki, vol. 5420, 2002.

[2] P. J. Tikalsky, J. Pospisil, and W. M. Donald, "A method for assessment of the freeze-thaw resistance of preformed foam cellular concrete," Cement and Concrete Research, 2004, vol. 34, no. 5, pp. 889-893.

[3] N. Narayanan and K. Ramamurthy, "Structure and properties of aerated concrete: a review," Cement and Concrete Composites, 2000. vol. 22, no. 5, pp. 321-329.

[4] M. Jones and A. McCarthy, "Preliminary views on the potential of foamed concrete as a structural material," Magazine of Concrete Research, 2005, vol. 57, no. 1, pp. 21-31.

[5] A. Tarasov, E. P. Kearsley, A. S. Kolomatskiy, and H. F. Mostert, "Heat evolution due to cement hydration in foamed concrete," Magazine of Concrete Research, 2010, vol. 62, no. 12, pp. 895-906.

[6] M. Jones and A. McCarthy, "Heat of hydration in foamed concrete: Effect of mix constituents and plastic density," Cement and Concrete Research, 2006, vol. 36, no. 6, pp. 1032-1041.

[7] H. Tanyildizi and A. Coskun, "Performance of lightweight concrete with silica fume after high temperature," Construction and Building Materials, 2008, vol. 22, no. 10, pp. 2124-2129.

[8] B. Chen and J. Liu, "Experimental application of mineral admixtures in lightweight concrete with high strength and workability," Construction and Building Materials, 2008, vol. 22, no. 6, pp. 11081113.

[9] S. Agarwal, "Pozzolanic activity of various siliceous materials," Cement and Concrete Research, 2006, vol. 36, no. 9, pp. 1735-1739.

[10] O. Kayali, "Fly ash lightweight aggregates in high performance concrete," Construction and Building Materials, 2008, vol. 22, no. 12, pp. 2393-2399.

[11] R. V. Balendran, F. P. Zhou, A. Nadeem, and A. Y. T. Leung, "Influence of steel fibres on strength and ductility of normal and lightweight high strength concrete," Building and Environment, 2002, vol. 37 , no. 12 , p. 1361-1367.

[12] BS EN 197-1, Cement-Part 1: Composition, Specifications and Conformity Criteria for Common Cements, British Standards Institution, London, 2011.

[13] BS 882, Specification for aggregates from natural sources for concrete, British Standards Institution, London, 1992.

[14] ASTM C144, Standard Specification for Aggregate for Masonry Mortar, 1987, American Society for Testing and Materials.

[15] K. Ruiwen, "Properties of high-strength foam concrete," MSc disserrtation, Department of Civil engineering, National University of Singapore, 2004.

[16] BS EN 405-1, Fly Ash for Concrete- Part 1: Defination, SpecificaTions and Conformity Criteria, 2005.

[17] E. Nambiar and K. Ramamurthy, "Fresh state characteristics of foam concrete," Journal of Materials in Civil Engineering, 2008, vol. 20, p. 111.

[18] K. Ramamurthy, E. Nambiar, and G. I. S. Ranjani, "A classification of studies on properties of foam concrete," Cement and Concrete Composites, 2009, vol. 31, no. 6, pp. 388-396.

[19] H. Toutanji and T. E. Korchi, "The influence of silica fume on the compressive strength of cement paste and mortar," Cement and Concrete Research, 1995, vol. 25, no. 7, pp. 1591-1602.

[20] G. Giaccio, G. R. D. Sensale, and R. Zerbino, "Failure mechanism of normal and high-strength concrete with rice-husk ash," Cement and Concrete Composites, 2007, vol. 29, no. 7, pp. 566-574.

[21] H. Tanyildizi, "Effect of temperature, carbon fibers, and silica fume on the mechanical properties of lightweight concretes," New Carbon Materials, 2008, vol. 23, no. 4, pp. 339-344.

[22] E. Nambiar and K. Ramamurthy, "Sorption characteristics of foam concrete," Cement and Concrete Research, 2007, vol. 37, no. 9, pp. 1341-1347. 
[23] A. Neville, Properties of Concrete, 5th ed. 2011, London Pearson Education Limited. 846.

[24] ASTM C796, Standard Test Method for Foaming Agent for Use in Producing Cellular Concrete Using Preformed Foam, 1997, American Society for Testing and Materials.

[25] K. Brady, G. Watts, and M. Jones, "Specification for foamed concrete," Highways Agency and TRL Application Guide AG, 2001. vol. 39.

[26] E. Nambiar and K. Ramamurthy, "Influence of filler type on the properties of foam concrete," Cement and Concrete Composites, 2006, vol. 28 , no. 5 , pp. $475-480$.

[27] BS EN 12390-3, Testing Hardened Concrete-Compressive StrenGth of Test Specimens, British European Standards Specifications, 2002.

[28] K. Jitchaiyaphum, T. Sinsiri, and P. Chindaprasirt, "Cellular lightweight concrete containing pozzolan materials," Procedia Engineering, 2011, vol. 14, pp. 1157-1164.

[29] Z. Pan, F. Hiromi, and T. Wee, "Preparation of high performance foamed concrete from cement, sand and mineral admixtures," Journal of Wuhan University of Technology, Materials Science Edition, 2007, vol. 22, no. 2, pp. 295-298.

[30] D. Babu, "Mechanical and deformational properties, and shrinkage cracking behaviour of lightweight concretes," PhD Thesis, Department of Civil Engineering. National University of Singapore, 2008.

[31] BS EN 12390-5, Testing Hardend Concrete- Part 5: Flexural StrenGth of Test Specimens, British Standards Institution, London, 2000.

[32] BS 1881-117, Testing concrete- Part 117: Method for determi-nation of tensile splitting strength, British Standards Institution, London, 1983.

[32] Fédération Internationale de la préContrainte, FIP Manual of Lightweight Aggregate Concrete, 2 ed. 1983, Glasgow: Surrey University Press.

[33] S. H. Ahmad and S. P. Shah, "Structural properties of high strength concrete and its implications for precast prestressed concrete," $P C I$ Journal, 1985, vol. 30, no. 6, pp. 92-119.

[34] F. Oluokun, Prediction of concrete tensile strength from its compressive strength: an evaluation of existing relations for normal weight concrete. ACI Materials Journal, 1991, vol. 88, no. 3.

[35] BS 1881-121, Testing concrete- Part 121: Method of DerermInation of Static Modulus of Elasticity in Compression, British Standards Institution, London, 1983.

[36] BS 8110, Structural Use of Concrete, Part 1: Code of Practice for Densign and Construction, British Standards Institution, London, 1985.

[37] M. Rashid, M. Mansur, and P. Paramasivam, "Correlations bet- ween mechanical properties of high-strength concrete," Journal of Materials in Civil Engineering, 2002, vol. 14, no. 3, pp. 230-238.

[38] BS 1881-203, Recommendations for Measurement of Velocity of Ultrasonic Pulses in Concrete, in British Standards Institution, London, 1986.

[39] K. Najim and M. R. Hall, "Mechanical and dynamic properties of self-compacting crumb rubber modified concrete," Construction and Building Materials, 2012, vol. 27, no. 1, pp. 521-530.

[40] P. K. Dehdezi, "Enhancing pavements for thermal applications," PhD Thesis, University of Nottingham, 2012.

[41] ISO 8301, Thermal Insulation - Determination of Steady-State Thermal Resistance and Related Properties - Heat Flow Meter Apparatus, in International Organization for tandardization, 1996: Genève, Switzerland.

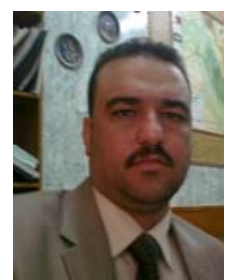

Ameer Hilal was born in Iraq in 1976. He obtained a B.Sc. in civil engineering in 1998 and M. Sc. in civil engineering in 2004 from Al-Anbar University, Iraq.

He worked as a research assistant (2002-2004), assistant lecturer (2004-2007) and lecturer (20072011) in the Department of Civil Engineering, College of Engineering, Al-Anbar University, Iraq.

$\mathrm{Mr}$ Hilal worked as a manager of the Engineering Consultant Bureau, Al-Anbar University from 2006 to 2010. He published 6 journal papers before coming to the UK (2011) to complete his PhD study. Now, he is a PhD student in Civil Engineering, Faculty of Engineering, The University of Nottingham, UK.

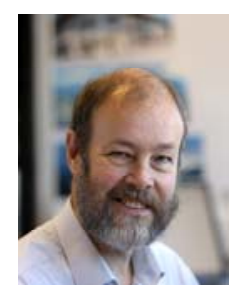

Nick Thom was born in London in 1956. He obtained a BA in engineering sciences from Cambridge University UK in 1977 and a PhD in pavement engineering from Nottingham University UK in 1988.

$\mathrm{He}$ worked as a graduate engineer and as an assistant resident engineer for Scott Wilson Kirkpatrick between 1978 and 1984. After obtaining his $\mathrm{PhD}$ he joined Scott Wilson Pavement Engineering as a pavement engineer, and since 1991 he has been a parttime Lecturer at the University of Nottingham UK while continuing to act as a Consultant, principally for for Scott Wilson (now URS). He is the author of 'Principles of Pavement Engineering' (Thomas Telford, London, 2008) and over 100 other technical publications. His research interests include construction materials, and pavement and railway design.

Dr Thom is a member of the Institution of Civil Engineers, UK, and the Chartered Institution of Highways and Transportation, UK

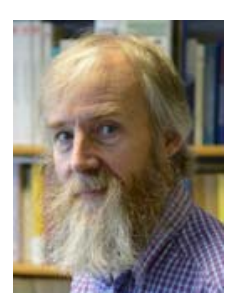

Andrew Dawson worked with major civil engineering contractors and civil engineering consultants on a wide variety of geotechnical work before moving to the University of Nottingham where he has been teaching and researching for more than 30 years in pavement, geotechnical, geological, geo-environmental, materials and sustainability engineering.

He chairs the US TRB Committee AFP70 (1) on Unbound Granular Materials. He led the European Road ERA-NET research project on Pavement Performance and Rehabilitation Requirements due to Climate Change working for a consortium of 10 national highway authorities in Europe. He was the chairman of the EU's COST351 research committee "Water Movements in Road Pavements and Embankments". He has written more than approximately 180 journal articles, conference papers, technical reports, and training manuals and has presented his work at many national and international meetings and conferences. Much of his research work in the last 20 years has been on the use of recycled and by-product materials in road construction (so as to reduce resource consumption) while maintaining water quality. He has also made particularly study of the opportunity for pavements to act as heat stores and solar heat collectors so as to offset their energy consumption in construction and maintenance. 